УДК 347.254.

DOI https://doi.org/10.32849/2663-5313/2020.5.04

\title{
Анна Мельник,
}

аспірантка кафедри иивільного права і процесу

Національної академії внутрішніх справ

\section{ДЕЯКІ ПИТАННЯ ЗАБЕЗПЕЧЕННЯ ВІЙСЬКОВОСЛУЖБОВЦІВ ТА ЧЛЕНІВ ЇХНІХ СІМЕЙ ЖИЛИМИ ПРИМІЩЕННЯМИ У ГУРТОЖИТКАХ}

Наголошено, що у зв'язку з недостатньою кількістю службового житла, а також з огляду на наявність поширеної практики виселення військовослужбовців та членів їхніх сімей з гуртожитків у судовому порядку, є необхідність аналізу основних положень забезпечення иієі категорії громадян жилими приміщеннями у гуртожитках, а також причин та підстав їх виселення. Мета статті - здійснити аналіз окремих питань забезпечення військовослужбовиів та членів їхніх сімей жилими приміщеннями у гуртожитках, зокрема вселення та виселення з гуртожитків, проаналізувати судову практику в спорах, що виникають під час виселення військовослужбовиів та членів їхніх сімей з гуртожитків. Так, у статті досліджено окремі питання забезпечення військовослужбовиів та иленів їхніх сімей жилими приміщеннями у гуртожитках, зокрема вселення та виселення з гуртожитків, проаналізовано судову практику в спорах, що виникають під час виселення військовослужбовиів та членів їхіх сімей з гуртожитків. Визначено, що адміністрачія підприємства, установи, організацій, орган місиевого самоврядування приймає рішення про надання особі жилої площі в гуртожитку. У рішенні зазначаються прізвище, ім'я, по батькові особи, якій надається жила площа в гуртожитку, склад сім'̈̈ та адреса гуртожситку, в якому надається жила площа. На підставі рішення про надання жилої площі в гуртожитку адміністращія підприємства, установи, організаиії, орган місцевого самоврядування видає особі ордер за формою згідно з додатком, який єє єдиим документом, що підтверджує право вселення на надану жилу плошу в гуртожитку. З'ясовано, що виселення колишніх иленів сім'і військовослужбовия з жилого примішення, а саме кімнати на території військового містечка та переобладнаної для тимчасового проживання військовослужбовиів стало предметом судового розгляду. Судом у иій справі встановлено, що згідно з умовами договору строкового користування жилим приміщенням, користувач зобов'язаний звільнити жиле приміщення після закінчення зумовленого в договорі строку проживання. Цей строк закінчився. Нове рішення про надання місия проживання в казармі відповідачки не приймалося та спеиіальний дозвіл на проживання в спечіально пристосованій казармі ій не видавався, так само такий дозвіл не видавався і ї̈ колишньому чоловікові (військовослужбовию).

Ключові слова: житло, житлове законодавство, виселення з гуртожитків, ордер, службове житло.

Постановка проблеми. Право кожного на житло гарантоване Конституцією України. 3 прийняттям Закону України «Про соціальний і правовий захист військовослужбовців та членів їх сімей» держава взяла на себе зобов'язання забезпечити військовослужбовців жилими приміщеннями або за їхнім бажанням грошовою компенсацією за належне їм для отримання жиле приміщення на підставах, у порядку і відповідно до вимог, встановлених Житловим кодексом УРСР та іншими нормативноправовими актами. Згідно з абзацом п'ятим пункту 1 статті 12 Закону України «Про соціальний і правовий захист військовослужбовців та членів їх сімей» [1] у разі відсутності службового жилого приміщення військовос- лужбовці рядового, сержантського і старшинського складу, які проходять військову службу за контрактом і не перебувають у шлюбі, розміщуються безплатно в спеціально пристосованих казармах у розташуванні військової частини, а сімейні - у сімейних гуртожитках. У зв'язку з недостатньою кількістю службового житла, а також з огляду на наявність поширеної практики виселення військовослужбовців та членів їхніх сімей 3 гуртожитків у судовому порядку, є необхідність аналізу основних положень забезпечення цієї категорії громадян жилими приміщеннями у гуртожитках, а також причин та підстав їх виселення.

Аналіз останніх досліджень і публікацій. Питання забезпечення громадян, у тому 
числі і військовослужбовців та членів їхніх сімей, жилими приміщеннями у гуртожитках досліджені у роботах М.К. Галянтича, Н.Ю. Голубєвої, Ю.О. Козацької, О.В. Оніщенко, С.О. Харитонова та ін.

Мета статті - здійснити аналіз окремих питань забезпечення військовослужбовців та членів їхніх сімей жилими приміщеннями у гуртожитках, зокрема вселення та виселення 3 гуртожитків, проаналізувати судову практику в спорах, що виникають під час виселення військовослужбовців та членів їхніх сімей з гуртожитків.

Виклад основного матеріалу. Згідно з абзацом п'ятим пункту 1 статті 12 Закону України «Про соціальний і правовий захист військовослужбовців та членів їх сімей» [1] у разі відсутності службового жилого приміщення військовослужбовці рядового, сержантського і старшинського складу, які проходять військову службу за контрактом і не перебувають у шлюбі, розміщуються безплатно в спеціально пристосованих казармах у розташуванні військової частини, а сімейні - у сімейних гуртожитках.

Згідно зі статтею 127 Житлового кодексу УРСР [2] для проживання робітників, службовців, студентів, учнів, а також інших громадян у період роботи або навчання можуть використовуватись гуртожитки.

Згідно зі статтею 131 Житлового кодексу УРСР Примірне положення про користування гуртожитками затверджується Кабінетом Міністрів України після консультацій з громадськістю, що проводяться відповідно до законодавства.

Таке Примірне положення про користування гуртожитками затверджене постановою Кабінету Міністрів України від 20 червня 2018 року № 498 [3] (далі - Примірне положення про користування гуртожитками), дія якого поширюється на всі гуртожитки незалежно від форми власності.

Пунктом 3 Примірного положення про користування гуртожитками визначено, що жила площа в гуртожитках надається:

у вигляді окремого жилого приміщення для відособленого користування однієї особи чи сім'ї;

у вигляді ліжко-місця для проживання одиноких осіб, які не перебувають між собою в сімейних відносинах.

Розмір жилої площі, що надається в гуртожитку, не може бути менше ніж 6 кв. метрів на одну особу.

Для одержання в користування жилої площі в гуртожитку особа подає заяву на ім'я керівника підприємства, установи, організації, органу місцевого самоврядування.
Повнолітні члени сім'ї особи, які бажають вселитися в жиле приміщення разом 3 нею, дають письмову згоду на проживання в зазначеному приміщенні.

Адміністрація підприємства, установи, організації, орган місцевого самоврядування приймає рішення про надання особі жилої площі в гуртожитку. У рішенні зазначаються прізвище, ім'я, по батькові особи, якій надається жила площа в гуртожитку, склад сім'ї та адреса гуртожитку, в якому надається жила площа

На підставі рішення про надання жилої площі в гуртожитку адміністрація підприємства, установи, організації, орган місцевого самоврядування видає особі ордер за формою згідно з додатком, який є єдиним документом, що підтверджує право вселення на надану жилу площу в гуртожитку. Під час одержання ордера пред'являються документи, що посвідчують особу наймача та всіх членів сім'ї (для осіб, які не досягли 14 років, - свідоцтва про народження), включених до ордера.

Ордер зберігається у особи, яка вселяється на жилу площу в гуртожитку, протягом усього строку її проживання у гуртожитку.

Аналогічну норму містить і стаття 129 Житлового кодексу УРСР, згідно з якою на підставі рішення про надання жилої площі в гуртожитку адміністрація підприємства, установи, організації, орган місцевого самоврядування видає громадянинові спеціальний ордер, який $є$ єдиною підставою для вселення на надану жилу площу в гуртожитку.

Так, у судовій справі № 554/18935/14-ц відсутність ордера встановленого зразка стала підставою для виселення з гуртожитку. Позивач у справі - Квартирно-експлуатаційний відділ у м. Полтаві Міністерства оборони України, відповідачі - колишній військовослужбовець та члени його сім'ї, третя особа - служба у справах дітей виконавчого комітету Октябрської районної у м. Полтаві ради, предмет - виселення з гуртожитку без надання іншого жилого приміщення.

За результатами апеляційного перегляду справи суд встановив, що відповідачам у справі ордер на спірне житлове приміщення не видавався, а також «з огляду на ту обставину, що житло зайняте відповідачами без належних правових підстав (без ордера) місцевий суд дійшов правильних висновків про задоволення позову... Доводи апеляційної скарги в частині того, що порушуються права неповнолітніх дітей також не спростовують висновків місцевого суду, оскільки, як зазначено вище, позивач не зобов'язаний забезпечувати житлом сім'ю відповідачів. Крім того, як зазначено вище, вселення 
в спірне житло проведено без належних правових підстав» [4].

Також впливає на рішення судів не тільки відсутність ордера на заселення, а і факт забезпечення військовослужбовців постійним житлом. Предметом апеляційного перегляду стала справа № 2/2218/1874/12 [5] за позовом Квартирно-експлуатаційного відділу міста Хмельницького до дружини колишнього військовослужбовця про виселення 3 гуртожитку. Приймаючи рішення про виселення відповідачки та іï неповнолітньої доньки, суд виходив 3 того, що «зазначена кімната в гуртожитку призначена виключно для проживання військовослужбовців Збройних сил України або осіб, які перебувають у трудових відносинах зі Збройними силами України.

Відповідачка та їі малолітня донька не мають самостійного права на зазначене житло в гуртожитку, позаяк відповідачка не $€$ військовослужбовцем, не перебувала і не перебуває в трудових відносинах як працівник $з$ жодною військовою частиною ... Їхне житлове право є похідним від права чоловіка та батька-військовослужбовця у відставці, який був забезпечений постійним житлом за рахунок Міністерства оборони України, двічі погіршував свої житлові права шляхом відчуження половини приватизованої квартири та подарованої цілої квартири, на квартирному обліку не перебуває, виписаний з гуртожитку» [5].

Згідно зі статтею 130 Житлового кодексу УРСР порядок користування жилою площею в гуртожитках визначається договором, що укладається перед вселенням на надану жилу площу в гуртожитку на підставі спеціального ордера відповідно до Примірного положення про користування жилою площею в гуртожитках, що затверджується Кабінетом Міністрів України.

Пунктом 7 Примірного положення про користування гуртожитками визначено, що користування жилою площею здійснюється:

у гуртожитках державної та комунальної форми власності - виключно за договором найму жилого приміщення, укладеним на підставі ордера;

у гуртожитках, що були включені до статутних капіталів господарських товариств створених у процесі приватизації та корпоратизації, - за договором найму жилого приміщення, укладеним на підставі ордера, або на підставі договору оренди житла.

Для укладення договору найму (оренди) 3 адміністрацією підприємства, установи, організації, органом місцевого самоврядування особа та всі члени її сім'ї, що вселяються на надану жилу площу в гуртожитку, пред’являють документи, що посвідчують особу (для осіб, які не досягли 14 років, - свідоцтва про народження).

Питанню виселення з гуртожитків присвячена стаття 132 Житлового кодексу УРСР, згідно з якою сезонні, тимчасові працівники і особи, що працювали за строковим трудовим договором, які припинили роботу, а також особи, що вчились у навчальних закладах і вибули з них, підлягають виселенню без надання іншого жилого приміщення з гуртожитку, який їм було надано у зв'язку з роботою чи навчанням.

Інших працівників підприємств, установ, організацій, які поселилися в гуртожитку в зв'язку з роботою, може бути виселено без надання іншого жилого приміщення в разі звільнення за власним бажанням без поважних причин, за порушення трудової дисципліни або скоєння злочину.

Осіб, які припинили роботу 3 інших підстав, ніж ті, що зазначені в частині другій цієї статті, а також осіб, перелічених у статті 125 цього Кодексу, може бути виселено лише 3 наданням їм іншого жилого приміщення.

Осіб, які проживають у гуртожитках, виселяють також у разі знесення будинку або переобладнання будинку (жилого приміщення) в нежилий, а також якщо будинок (жиле приміщення) загрожує обвалом. При цьому тим, кого виселяють, надається інша жила площа в гуртожитку або інше жиле приміщення.

Особливості виселення 3 гуртожитків Міністерства оборони України визначені Інструкцією з організації забезпечення військовослужбовців Збройних сил України та членів їхніх сімей жилими приміщеннями, затвердженою наказом Міністерства оборони України від 31 липня 2018 року № 380 та зареєстрованою в Міністерстві юстиції України 06 вересня 2018 року за № 1020/32472 [6] (далі - Інструкція Збройних сил України № 380), згідно з пунктом 25 розділу IV якої підлягають виселенню із службового жилого приміщення (зі службової жилої площі) без надання іншого жилого приміщення:

військовослужбовці та члени їхніх сімей, які порушують умови утримання жилих приміщень, систематично його руйнують чи використовують його не за призначенням, або створюють умови, які унеможливлюють проживання інших осіб;

особи, звільнені з військової служби, які мають вислугу менше ніж 10 років, крім випадків, передбачених законодавством;

особи, які самоправно зайняли службове житлове приміщення (службову житлову площу); 
колишні члени сім'ї військовослужбовця, які залишилися проживати у ньому після розірвання шлюбу (у двомісячний строк з дня розірвання шлюбу);

інші особи у випадках, встановлених законодавством.

Так, Котовським міськрайонним судом Одеської області у справі № 505/1497/15-ц за позовом Квартирно-експлуатаційного відділу міста Одеси до колишньої дружини військовослужбовця про виселення прийняв рішення виселити відповідачку з гуртожитку без надання іншого житлового приміщення. Своє рішення Суд мотивував тим, що відповідачка заселилась у гуртожиток у складі сім’ї військовослужбовця, згодом шлюб було розірвано, військовослужбовець виїхав з гуртожитку, вона не є військовослужбовцем або членом сім'ї військовослужбовця, добровільно більше двох років не проживає в гуртожитку, є такою, що втратила право користування кімнатою.

Крім того, «невиконання відповідачкою обов'язку про звільнення житлового приміщення у гуртожитку призведе до порушення права на житло інших громадян, які справді проходять військову службу у ЗС України та не мають житла за місцем проходження служби.

Таким чином, оскільки відповідачі не перебувають на військовій службі у ЗСУ та не перебувають на обліку військових пенсіонерів та військовослужбовців, які потребують поліпшення житлових умов у гарнізоні, тому не мають права на проживання у гуртожитку МОУ і підлягають виселенню без надання іншого жилого приміщення» [7].

Аналогічної позиції дотримався суд, переглядаючи в апеляційному порядку справу № 405/5250/13-ц за позовом Квартирно-експлуатаційного відділу м. Кіровограда до членів сім'ї військовослужбовця про виселення. Військовослужбовцю та членам його сім'ї (дружині та її дитині) на час проходження служби було надано кімнату в казармі, що пристосована для тимчасового проживання. Шлюб між ними було розірвано, а військовослужбовця переведено до нового місця проходження служби.

Так, суд дійшов висновків, що «право відповідачів на проживання у спірній кімнаті $€$ похідним від права на отримання і проживання у цій кімнаті військовослужбовця. Оскільки право військовослужбовця на проживання у цій кімнаті припинилося у зв'язку зі зміною місця проходження військової служби, відповідачі вже не є членами його сім'ї та військовослужбовцями, право на проживання у цій кімнаті вони втратили... Є безпідставними і доводи скарги щодо неза- конного позбавлення житла неповнолітньої доньки та матері оскаржуваним рішенням суду, оскільки зазначені особи не набули у встановленому законом порядку права на проживання у спірній кімнаті, а позбавити осіб неіснуючого права неможливо» [8].

Згідно з пунктом 26 розділу IV Інструкції Збройних сил України № 380, особи, звільнені з військової служби, які були забезпечені службовим жилим приміщенням, жилою площею у гуртожитку (сімейному гуртожитку) та залишені на обліку військовослужбовці та члени їхніх сімей, які потребують поліпшення житлових умов шляхом надання жилих приміщень для постійного проживання, не підлягають виселенню до забезпечення іх постійним житлом за встановленим порядком.

Згідно зі статтею 125 Житлового кодексу УРСР без надання іншого жилого приміщення не може бути виселено:

осіб 3 інвалідністю внаслідок війни та інших осіб з інвалідністю 3 числа військовослужбовців, які стали особами з інвалідністю внаслідок поранення, контузії або каліцтва, що їх вони дістали під час захисту СРСР чи під час виконання інших обов’язків військової служби, або внаслідок захворювання, пов'язаного 3 перебуванням на фронті; учасників Другої світової війни, які перебували у складі діючої армії; сім’ї військовослужбовців і партизанів, які загинули або пропали безвісти під час захисту СРСР чи під час виконання інших обов'язків військової служби; сім'ї військовослужбовців; осіб 3 інвалідністю $з$ числа осіб рядового і начальницького складу органів Міністерства внутрішніх справ СРСР, які стали особами 3 інвалідністю внаслідок поранення, контузії або каліцтва, що їх вони дістали під час виконання службових обов'язків;

осіб, які пропрацювали на підприємстві, в установі, організації, що надали їм службове жиле приміщення, не менш як десять років;

осіб, що звільнені з посади, у зв'язку з якою їм було надано жиле приміщення, але не припинили трудових відносин з підприємством, установою, організацією, які надали це приміщення;

осіб, звільнених у зв'язку з ліквідацією підприємства, установи, організації або за скороченням чисельності чи штату працівників;

пенсіонерів по старості, персональних пенсіонерів; членів сім'ї померлого працівника, якому було надано службове жиле приміщення; осіб з інвалідністю внаслідок нещасного випадку на виробництві або професійного захворювання I і II груп, осіб 
3 інвалідністю I і II груп з числа військовослужбовців і прирівняних до них осіб та осіб рядового і начальницького складу Державної служби спеціального зв'язку та захисту інформації України;

одиноких осіб з неповнолітніми дітьми, які проживають разом 3 ними.

Умови, які виключають можливість виселення із гуртожитку без надання іншого приміщення, беруться судом до уваги як у разі, коли вони виникли на момент припинення трудових відносин, так і після, до вирішення судом справи про виселення [9, с. 292].

На думку О.В. Оніщенко та Ю.О. Козацької, «єдиною наразі можливістю сприяння підвищенню соціальних конституційних гарантій для законних мешканців гуртожитків є встановлення мораторію на виселення громадян із гуртожитків, проте такий законопроєкт лише опрацьовується, коли його буде прийнято, і чи буде прийнято взагалі невідомо» [10, с. 112].

Не можемо погодитись із зазначеною позицією, оскільки основна функція гуртожитків - проживання громадян на період їх роботи або навчання, і передача їх у власність громадян, зокрема тих, кого може бути виселено без надання іншого житла, значно скоротить кількість службової житлової площі військових формувань, що є неприпустимим 3 огляду на кількість військовослужбовців, які потребують поліпшення житлових умов.

Що стосується заборони на виселення з гуртожитків без надання іншого житла осіб, які пропрацювали на підприємстві, в установі, організації, що надали їм службове жиле приміщення, не менш як десять років зазначаємо таке.

Законодавством прямо не визначено, чи повинен такий стаж бути безперервним чи сумарним, а отже, на думку деяких учених, «особи, які пропрацювали на підприємстві, в установі, організації, що надали їм жиле приміщення, не менше 10 років, користуються такою пільгою і в тому разі, коли цей стаж переривався» [9, с. 292].

Відмовляючи в задоволенні позову щодо виселення з гуртожитку без надання іншого житла у справі № 760/13777/15-ц судом встановлено, що «з огляду на положення ст.ст. 125, 132 ЖК Української PCР, у разі припинення трудових відносин, осіб, які пропрацювали на підприємстві, в установі, організації, що надали їм службове жиле приміщення, не менш як десять років, може бути виселено із гуртожитку за умови надання іншого житлового приміщення. Як видно з матеріалів справи, вислуга років відповідача
ОСОБА_1 на момент звільнення становила 12 років 11 місяців 14 днів. Таким чином, беручи до уваги зазначені обставини, суд доходить висновку, що, оскільки відповідач ОСОБА_1 пропрацював в органах УДСО більше $1 \overline{0}$ років, на нього поширюються гарантії, встановлені ст. 125 ЖК Української РСР» [11].

Неможливість виселення особи з вислугою понад 10 років не стала вирішальною у справі № 759/12754/15-ц за позовом Управління Державної служби охорони при ГУМВС України в м. Києві до колишнього міліціонера, його дружини та трьох неповнолітніх дітей про виселення. Незважаючи на наявність у звільненого (за службову невідповідність) співробітника календарної вислуги понад 15 років, апеляційний Суд дійшов висновку, що «відповідач разом із сім'єю проживає в кімнаті гуртожитку УДСО № 4-2 за АДРЕСА 1 без відповідної правової підстави, а тому вимоги позивача $€$ обгрунтованими на законі, доведеними матеріалами справи та такими, що підлягають задоволенню, а саме виселити ОСОБА 1, ІНФОРМАЦІЯ_7, ОСОБА_2, ІНФОРМАЦІЯ 8, неповнолітніх ОСОБА 3, ІНФОРМАЦІЯ_9, ОСОБА_4, ІНФОРМАЦІЯ 10, ОСОБА 5, ІНФОРМАЦІЯ 11, 3 кімнати № 4-2 гуртожитку УДСО при ГУ МВС України в м. Києві за адресою: АДРЕСА_1 без надання іншого житлового приміщення» [12].

Аналогічної позиції дотримався суд, приймаючи рішення у справі № 683/2598/13ц, відповідно до якого «з матеріалів справи видається, що ОСОБА_4 з 20.05.1997 p. по 18.11 .1998 р., з $19.08 .19 \overline{9} 9$ р. по 19.08.2008 р. проходив службу у Збройних силах України, однак він не перебуває на обліку осіб, які потребують поліпшення житлових умов у ЗС України, а тому незалежно від кількості вислуги років у календарному обчисленні він та члени його сім'ї: дружина ОСОБА_5 та дочка ОСОБА_6 не набули законних прав на проживання у гуртожитку і підлягають виселенню з нього без надання іншого житлового приміщення» [13].

Рішення деяких судів узагалі містять висновок про те, що «оскільки жиле приміщення є гуртожитком, а не службовим житловим приміщенням, суд першої інстанції дійшов обгрунтованого висновку, що ОСОБА 1 із сім'єю не може бути виселена 3 нього 3 підстав ст.ст. 124, 125 ЖК України. Вказані норми права на приміщення в гуртожитках не поширюються» [14].

Предметом судового розгляду справи № 127/15531/15-ц за позовом Квартирноексплуатаційного відділу м. Вінниці до вій- 
ськовослужбовця та членів його сім'ї стала вимога про виселення останніх 3 кімнати у гуртожитку без надання їм іншого житла.

У ході судового розгляду справи суд встановив, що військовослужбовця переведено для подальшого проходження військової служби до іншого військового формування та іншого гарнізону (до м. Харкова), надано за новим місцем проходження військової служби йому та членам його сім'ї службове житло (яке вони надалі приватизували), фактично в кімнаті гуртожитку відповідачі не проживають, оскільки проживають у Харківській області, проте займають кімнату, в якій зберігають свої речі.

Також суд дійшов висновку, що відповідачі підлягають виселенню 3 кімнати в гуртожитку без надання іншого житла на підставі ч. 2 ст. 132 ЖК УРСР, оскільки «гуртожиток № 20 по вул. Червоноармійській у м. Вінниці призначений лише для проживання військовослужбовців, а також враховуючи явну потребу суспільства у житлі (на обліку осіб, які потребують житлової площі в гуртожитку, перебуває більше 100 військовослужбовців із членами сім'ї)» [15].

Виселення колишніх членів сім'ї військовослужбовця 3 жилого приміщення, а саме кімнати на території військового містечка та переобладнаної для тимчасового проживання військовослужбовців стало предметом судового розгляду (справа № 761/4826/15ц). Судом у цій справі встановлено, що згідно з умовами договору строкового користування жилим приміщенням користувач зобов'язаний звільнити жиле приміщення після закінчення обумовленого в договорі строку проживання. Цей строк закінчився. Нове рішення про надання місця проживання в казармі відповідачки не приймалося та спеціальний дозвіл на проживання в спеціально пристосованій казармі їй не видавався, так само такий дозвіл не видавався і її колишньому чоловікові (військовослужбовцю).

Суд прийняв рішення про виселення колишньої дружини з житлового приміщення у казармі, посилаючись на статтю 116 Житлового кодексу УРСР, згідно з якою осіб, які самоправно зайняли жиле приміщення, виселяють без надання їм іншого жилого приміщення [16].

\section{Висновки}

Отже, питання виселення військовослужбовців та членів їхніх сімей з гуртожитків без надання іншого житла спричиняє неоднакове застосування судами норм матеріального права, а тому потребує подальшого законодавчого врегулювання.

\section{Список використаних джерел:}

1. Закон «Про соціальний і правовий захист військовослужбовців та членів їх сімей». Biдомості Верховної Ради Украӥни від 14.04.1992-1992 р., № 15, стаття 190 .

2. Житловий кодекс Української PCP. URL: https://zakon.rada.gov.ua/laws/show/5464-10.

3. Примірне положення про користування гуртожитками, затверджене постановою Кабінету Міністрів України від 20 червня 2018 року № 498. URL: https://zakon.rada.gov.ua/laws/ show/498-2018-\%D0\%BF.

4. Ухвала Апеляційного суду Полтавської області від 18 травня 2015 року. Єдиний державний реєстр судових рішень. URL: http://reyestr.court. gov.ua/Review/44513890.

5. Рішення Апеляційного суду Хмельницької області від 6 червня 2012 року. Єдиний державнии реєстр судових рішень. URL: http://www.reyestr. court.gov.ua/Review/24566848.

6. Інструкція з організації забезпечення військовослужбовців Збройних сил України та членів їх сімей жилими приміщеннями, затверджена наказом Міністерства оборони України від 31 липня 2018 року № 380 та зареєстрована в Міністерстві юстиції України 06 вересня 2018 року за № 1020/32472. URL: https://zakon. rada.gov.ua/laws/show/z1020-18.

7. Рішення Котовського міськрайонного суду Одеської області від 22 січня 2016 року. Єдиний державний реєстр судових рімень. URL: http://www.reyestr.court.gov.ua/Review/55896536.

8. Ухвала Апеляційного суду Кіровоградської області від 20 травня 2014 року. Єдиний державний реєстр судових рішень. URL: http://www.reyestr. court.gov.ua/Review/38762514.

9. Житловий кодекс України : науково-практичний коментар / За загальною редакцією д.ю.н., професора Є.О. Харитонова, к.ю.н., доцента Н.Ю. Голубєвої. Харків : «Одіссей». 2010. 480 с.

10. Оніщенко О.В. Приватизація житлових кімнат у гуртожитках: проблеми сьогодення / О.В. Оніщенко, Ю.О. Козацька. Юридичний вісник. Повітряне і космічне право. 2016. № 3. C. 106-112. URL: http://nbuv.gov.ua/UJRN/Npnau_2016_3_19.

11. Рішення Соломянського районного суду міста Києва від 10 травня 2016 року. $€ \partial u$ ний державний реєстр судових рішень. URL: http://reyestr.court.gov.ua/Review/73616499.

12. Рішення Святошинського районного суду міста Києва від 22 березня 2016 року. $\epsilon \partial u$ ний державний реєстр судових рішень. URL: http://reyestr.court.gov.ua/Review/56762565.

13. Рішення Старокостянтинівського районного суду Хмельницької області від 13 лютого 2014 року. ЄӘиний державний реєстр судових рішень. URL: http://reyestr.court.gov.ua/ Review/37916277.

14. Ухвала Апеляційного суду Чернівецької області від 12 березня 2014 року. Єдиний державний реєстр судових рішень. URL: http://reyestr. court.gov.ua/Review/37584206. 
15. Рішення Вінницького міського суду Вінницької області від 11 січня 2016 року. Єдиний державний реєстр судових рішень. URL: http:/ reyestr.court.gov.ua/Review/55040776.
16. Постанова Апеляційного суду міста Києва від 27 січня 2016 року. Сдиний державний реєстр судових рішень. URL: http://www.reyestr.court. gov.ua/Review/55380033.

It is emphasized that due to the insufficient number of official housing, as well as the existence of widespread eviction of servicemen and their families from hostels in court, there is a need to analyse the main provisions of providing this category of citizens with accommodation in hostels, as well as the reasons and the grounds for their eviction. The purpose of the article is to analyse the specific issues of providing servicemen and their families with dormitories, including moving in and out of hostels, to analyse the jurisprudence in disputes arising from the eviction of servicemen and their families from hostels. Thus, the article explores the specific issues of providing servicemen and their families with dormitories, in particular, eviction and eviction from hostels, analyses case law in disputes arising from the eviction of servicemen and their families from hostels. It has been determined that the administration of an enterprise, institution, organization, body of local selfgovernment makes a decision on providing a person with living space in a hostel. The decision shall indicate the name, patronymic of the person to whom the living space in the hostel is provided, the composition of the family and the address of the hostel in which the living space is provided. Based on the decision to provide living space in a dormitory, the administration of an enterprise, institution, organization, body of local selfgovernment issues to the person a warrant in the form according to the appendix, which is the only document confirming the right of occupation of the given living space in the hostel. It has been found that the eviction of former members of his family from a residential area, namely a room on the territory of a military town and a temporary accommodation for servicemen, has become subject to judicial review. The court in this case found that according to the terms of the contract for use of residential premises, the user is obliged to vacate the residential premises after the expiration of the term of residence specified in the contract. This deadline has expired. The new decision to provide the place of residence in the barracks of the defendant was not made and a special permit to reside in a specially adapted barracks was not issued to her, and the same permission was not issued to her ex-husband (serviceman).

Key words: housing, housing legislation, hostel eviction, warrant, office accommodation. 